\title{
Understanding Citizenship: The Functionalist Approach
}

\begin{abstract}
This chapter starts by explaining why a theoretically informed inquiry is needed. Such an inquiry is warranted for a number of reasons that include political volatility, lack of relevant precedents and the fact that conventional approaches do not lead to many policy suggestions for solving the hard cases at hand. It is suggested that Brexit may place us before a constitutional dilemma: Can Article 50 be taken seriously without giving up rights? The functionalist theory that this study adopts is outlined and explained. Three ways in which it applies to Brexit are distinguished. These three directions of inquiry are developed in the rest of the book.
\end{abstract}

Keywords European citizenship - Functionalist theory of citizenship . Brexit · EU law

\subsection{Four Arguments in Favour of Theory}

A theoretically informed inquiry is needed, I submit, to understand European citizenship after Brexit. An explanation is needed on why we ought to abandon the more traditional or mainstream analysis of the issue that has hitherto prevailed both among scholars and in the media. There are a number of reasons for favouring a different approach. These include the political volatility surrounding the matter, the lack of relevant precedents and the fact that conventional approaches offer few or no policy suggestions for solving the hard cases at hand. But

(C) The Author(s) 2017

P. Mindus, European Citizenship after Brexit, Palgrave Studies in European Union Politics, DOI 10.1007/978-3-319-51774-2_4 
there are also more deep-seated reasons why a different kind of approach to the matter is needed. Some are starting to sense that a choice has to be made: Are we serious about the exit or about safeguarding rights? In what follows, four arguments are made in favour of a theoretical take.

The first reason is dictated by circumstance: the political volatility surrounding the matter suggests avoiding predictive activities. It is imperative to determine if, and which, 'acquired rights' will be upheld - in itself a 'dauting task,' to use the phrasing adopted by the EU committee report, entitled The Process of Withdrawing from the European Union and drafted at the request of the House of Lords in 2015 (House of Lords 2015).

As things currently stand, outcomes of negotiations cannot be foreseen. Focus here will be on determining what resources, if any, are available to the legal scholar regardless of what may happen politically. I will therefore operate under the assumption agreement-less withdrawal.

Many have pointed out the unlikelihood of non-negotiated withdrawal. Yet, in this study I will discuss this possibility (or a withdrawal treaty making no mention of free movement rights, which for the present purposes would amount to the same thing). I have chosen to operate under this assumption because the question of remedies in the absence of an agreement is relevant since there is no guarantee that any agreement would have terms that are favourable to all affected groups and/or that any agreement would claim comprehensiveness.

In the next chapter of the book, I scrutinise the extra-negotiational resources able to 'freeze' what is often described as the 'transnational individual rights of EU citizens' so as to point out some limits to political engineering. Despite the unquestionable existence and importance of the political dimension, the primary focus is on the legal nature of the consequences of Brexit for the laws governing nationality, EU citizenship status and connected rights.

The second reason that suggests we avoid adopting mechanically the approaches we find in mainstream legal research is the unprecedented character of Brexit. The very framing of the unprecedented nature of the problem requires some reflection and it raises a number of very important issues, a point which was made clear in the wake of the High Court's decision on 3 November 2016 concerning the issue of whether the government needs to obtain approval from Parliament to trigger Article 50 (see, e.g. Peers 2016). There is much novelty in what is happening: Invoking Article 50 is certainly uncharted territory (Craig 2016). 
It is not, however, the first time in the history of European integration that the territorial scope of application of the Treatises changes. Previous modification of territorial validity include the following: In 1975 the EC Treaties ceased to cover the French Commodores and the island of Mayotte, which however is now EU overseas territory; the same happened in Dutch New Guinea (1962); Algeria (1962); Greenland (1985); Saint Barthémely (2003). European integration history also includes cases of member state territory declared to fall outside the scope of the Treatises: suffice to mention, for example, Faroe, Macao, Hong Kong, Surinam and the UK Sovereign Base Areas in Cyprus, as well as territories that joined after the member state joined: for example, Netherlands Antilles and the Canary Islands (Kochenov 2011). To be precise, more than half of what used to be member states' territory have 'left' since the creation of the Communities (Ziller 2005). The reference is to the Belgian territories of Congo, Rwanda-Burundi, Italian protectorate of Somalia, the Netherlands, New Guinea, French equatorial Africa, French East-Africa, the protectorates of Togo and Cameroon, the Commodores Islands, Madagascar, the Côte Française des Somalis; and following the accession of the UK, also Bahamas, Brunei, the Caribbean Colonies and Associated States, Gilbert and Ellis islands, the Line Islands, the AngloFrench condominium of the New Hebrides, the Solomon Islands and the Seychelles.

Yet, there is no relevant precedent, when reviewing the territorial changes that have taken place in the 'territory of the Union,' which can be applied in strict analogy to Brexit. Not even the independence of Algeria, the 'withdrawal' of Greenland, nor the most recent modification of EU territory, that is, the case of Saint Barthélemy, can be fully compared with Brexit. Saint Barthémely had a previous status as départment belonging to Guadaloupe, but after the 2003 referendum the island became a 'communauté d'outre mer' as defined in Art. 79 Constitution Française.

Algeria would probably be the closest precedent, if any were to be indicated. Yet, the events were such that the analogy does not hold: Between 1962 and 1975, when Algeria concluded a treaty with the EEC, the Treaties were nonetheless 'valid by implication' (sic!), but Algerians lost the status of member state nationals for the purposes of Community law (Laffont 1979). In February 2004 the European Commission answered a parliamentary question that queried the precedential value of Algerian independence for a division of a member state 
and whether the region in question would have to leave the EU and renegotiate an accession treaty and the answer was that a part of member state territory upon gaining independence is from EU perspective a third country in which EU law is not valid. A fortiori, this is the case of a receding state.

Greenland is often mentioned in the media and by certain scholars, but it is even more misleading. Greenland never did exit. Following a vote in 1982, Greenland officially 'withdrew' from the European communities in 1985. There were difficult and protracted negotiations between the governments of Greenland and Denmark, and between Denmark and the Commission, particularly with regard to fisheries. Greenland became associated with the EU as an Overseas Country and Territory (OCT) through the Greenland Treaty. ${ }^{1}$ The Article 2 of the Protocol attached to the Greenland Treaty clarified that there would be a transitional period during which Greenlanders, non-national residents and businesses with acquired rights under EU law would retain these rights. ${ }^{2}$ The agreement applied to Greenland is hard to define as any kind of 'exit.' Greenland simply changed its status under the Treatises to an Overseas Country or Territory in the sense of Annex II.

Another reason why the analogy with Greenland fails is political: Because the Brexit debate regarded immigration, we should rule out that, were the UK to leave without any negotiated transitional measures, it would retain free movement tout court. When Greenland 'left' the EU, the Commission considered that vested rights meant Greenland should retain 'the substance' of free movement rights for workers from other EC countries employed in Greenland at the time of withdrawal:

Provision should be made for appropriate measures to protect companies and persons who have exercised the right of establishment as well as Community workers employed in Greenland. The extremely small number of persons affected and the case-law of the Court of Justice that has already been established in favour of the retention of pension rights acquired by workers during periods of employment in a territory which has subsequently ceased to belong to the Community give no reason to suppose that there will be any major difficulties in this area, even if the future status of Greenland were to rule out the principle of free movement. It would, however, be preferable to retain the substance of the Community rules, at least in respect of Community workers employed in Greenland at the time of withdrawal. ${ }^{3}$ 
The Commission did not say whether the rest of the EU should retain these rights for workers from Greenland.

None of the cases mentioned can be said to constitute precedents. This fact suggests that traditional comparative legal readings may therefore be inappropriate.

Let alone the political volatility and the unprecedented character of the case at hand, there is a third reason suggesting we adopt a better-reasoned approach. It pertains to the legal uncertainty affecting many on both sides of the emerging border. The complexities involved in finding remedial solutions calls for an assessment that avoids jumping to incautious conclusions. A complete overview of remedial options to enforce 'vested rights' in EU27 for UK nationals stripped of Treaty rights is a complicated affair. It is a matter of national law that would depend on the individual provisions of each member state's domestic public and administrative law.

The conventional wisdom has it that Union citizenship follows national citizenship like a shadow follows the body that carries it along. From here springs the commonly made assumption that entitlements vanish when access criteria are no longer fulfilled. This is, in my view, due to the way citizenship is, often but not always, conceived in legal science. Most lawyers confuse the meaning of status civitatis with criteria for access and loss of the status. ${ }^{4}$ Indeed, ask 'what is citizenship?' and the standard answer will invariably involve reference to the principles of ius soli and ius sanguinis that regulate access criteria. This instinctive reaction leads to the often-repeated claim that no treaty rights can thus be guaranteed to those who are ipso facto no longer European citizens: Good riddance to the Treaty rights of Brits living in the Union! Neither can Treaty rights be enforced beyond the scope of application of the Treatises: Good luck to European citizens in the UK! This approach undermines the search for smart policy suggestions. I prefer to offer a better-informed view of the relationship between loss of the status, and the content of European citizenship. Status civitatis, after all, is a conceptual bridge linking the criteria for acquisition and loss to the entitlements the status consists in.

Finally, a last reason to think well about the way we approach the issue of Brexit depends on the fact that the stakes are high. This is not only due to the foreshadowed political circumstances, general novelty and legal ambiguity but also due to the very significance of Brexit for Union citizenship. The way issues raised by Brexit, especially in relation to 'citizenship rights,' will be tackled is revealing of the nature of Union citizenship and of the strength, or weakness, of the vertical link between the Union and its 
citizens. Who has the competence to withdraw the status of Union citizenship? What are the limits to the 'sovereign right to exclude'? Are these limits sufficient for making the case that European citizenship is 'the fundamental status' of 'those who find themselves in the same situation to enjoy the same treatment in law irrespective of their nationality ${ }^{5}$ according to a federal-constitutional reading? ${ }^{6}$ Or do these limits show that the 'rights' attached to the status are more truthfully framed, in the intergovernmental perspective on European citizenship, as 'privileges' or 'concessions' that are 'mutually recognised'? ${ }^{7}$ Looking into the extranegotiational resources for 'freezing rights' is important from this perspective because to answer these questions means to confront a dilemma:

One horn of the dilemma is constituted by the claim that supranational rights constitute European citizenship and cannot be erased at will by the withdrawing state; the other horn is constituted by the claim that they may very well be suppressed if a member state decides to exit. The European Court of Justice (ECJ) stated back in 1963 in the case Van Gend and Loos that such rights are part of individuals' 'legal heritage.' Would this imply that 'such acquired rights cannot be immediately and directly extinguished'? (Douglas-Scott 2015). Will rights exercised under EU law be recognised as part of individuals' legal heritage, outlasting the legal provisions that created it? Or would such a reading violate the very spirit of exiting, according to the view that imposing [European citizenship and relative rights-protection] on the people of a member state who just voted to leave the Union would be nothing but a direct attack on the letter and purpose of the provision making withdrawals possible'? (Kochenov 2016; also Athanassiou and Laulhé Shaelou 2016). Can't the 'acquired rights' of people having made use of their free movement be frozen without rending futile the attempt of a country to exit the Union? Would such a freezing mean that European citizenship deprives Article $\mathbf{5 0}$ of its effet utile? To some, the issue is nothing less than a constitutional test: 'The de-coupling of European from national citizenship in the CJEU's case-law has already begun to shift citizens' entitlement to jointly decide about membership in the polity from the national to the European level. Extending that primordial political right to the case of the UK leaving the Union would certainly amount to a coup d'état' (Dawson and Augenstein 2016).

Put this way, the dilemma looks like a choice between Scylla and Charybdis: Sacrificing EU citizens' rights on the altar of democratic selfdetermination or - if rights are substantially maintained and content of 
Union citizenship left unaltered - sacrifice the will of the people to withdraw on the altar of individual rights. The risk of facing such a dilemma warrants the rest of this inquiry.

\subsection{Applying Citizenship Theory to Brexit}

\subsubsection{The Functionalist Theory}

Citizenship, conceptually speaking, is a so-called middle-term. ${ }^{8}$ This is the starting point of the functionalist theory of citizenship, which is a general theory of citizenship that provides a framework for de lege ferenda analysis of citizenship laws. A general theory of citizenship, to be such, needs to describe the relationship between entitlements and access criteria. Entitlements are about what citizenship consists in. Access criteria determine to whom the status is conferred. These two dimensions constitute the concept's extension and intension, in the philosophical sense.

Extension is determined by answering the query 'Who is the citizen?' To answer such a query is to give a list of criteria for acquisition and loss of the status. These criteria give us information about which persons are denoted by the term. Intension is determined by the query 'What is a citizen?' To answer such a query is to indicate a set of entitlements or legal positions typically rights and duties. To determine intension is therefore to indicate the content of citizenship. Intension, in other words, defines the properties connoted by citizenship.

Both intension and extension vary. This has led many to conclude that we cannot know beforehand anything about the variation. This is wrong. The two dimensions do not vary indefinitely. Their variation is intelligible and can be studied. The illusion of indefinite and rationally uncontrollable variation arises when one studies one dimension of citizenship separately from the other.

Emboldened by this insight, the functionalist theory develops two ideas: The constitutional-sensitivity thesis and the correlation thesis.

The constitutional-sensitivity thesis submits that information on citizenship, in its combined form, consisting both of access criteria and entitlements, is a source of constitutional meta-data: The variation of extension (i.e. criteria for acquisition and loss) in relation to intension (i.e. legal positions associated with the status) provides information about the constitutional identity of a polity. This is so because nationality law is not just any area of law. The power to define the demos, to determine who 
counts as citizens - the flip side of the state's 'power to exclude' - is essential to the existence and identity of the state. There is a correlation between the role of the citizenry and nature of the polity (Mindus 2016). To define this role attention needs to be paid to both entitlements connected to the status and criteria for acquisition and loss. Access to citizenship regulates how the demos (or set of citizens) is composed; and entitlements determine their share of power. The composition and role of the demos in a legal order is determinative of its constitutional identity. Ever since Aristotle, the number of people allowed to hold office and share political power constitutes a measure defining the form of government. ${ }^{10}$ This is the fundamental intuition behind the constitutional-sensitivity thesis.

According to the correlation thesis, access to status civitatis is not neutral, but can be conceived as a variable of the content of the status. There is a relationship between the two dimensions that is best described as a functional correlation, in the mathematical meaning of function. This correlation is functional in the sense that criteria giving access to the status and the type of entitlements it entails have to be aligned so that access criteria fit the particular type of entitlements connected to the status. If they are not aligned by functional correlation, citizenship becomes an arbitrary instrument of social closure: As if we were to distinguish insiders from outsiders randomly. Who is eligible for citizenship is a question that depends on the features required to enjoy the entitlements and perform the duties of citizenship. Which characteristics, capabilities, distinctive features are relevant, and reasonable to require, depends on the type of rights and obligations that a given 'citizenship' consists in. Therefore access to the status is functionally correlated to the content of it. Changing one impacts the other. The functional correlation can be expressed as follows:

I use the term codomain (C) to refer to extension (i.e. criteria for acquisition and loss of citizenship) and domain (D) to refer to intension (entitlements or legal positions associated with the status). Both are nonempty sets. ${ }^{11}$ The domain is the set of the arguments for which the function is defined; the codomain is the target set. No submission is made about cardinality at this stage.

$$
\begin{aligned}
& \mathrm{C}=\left\{c_{1}, c_{2} \ldots c_{n}\right\} \\
& \mathrm{D}=\left\{d_{1}, d_{2, \ldots} . . d_{n}\right\}
\end{aligned}
$$


The correlation thesis claims that criteria for acquisition and loss of the status constitute a function of the entitlements it consists in. Symbolically, it can be summarised in the following way:

$$
f: \mathrm{D} \rightarrow \mathrm{C}
$$

In other words, $f$ is a surjective function from $\mathrm{D}$ to $\mathrm{C}$ so that:

$$
\forall c \in \mathrm{C}, \exists d \in \mathrm{D}, f(d)=c
$$

The function is surjective because every point in the codomain is the value of $f(d)$ for at least one point $d$ in the domain.

We can operate in two ways to better understand a particular case of status civitatis: Given a set of criteria of acquisition and loss, the intension that can be connected to such an extension may be inferred. Otherwise said, if we have knowledge about criteria for acquisition and loss, we may infer compatible entitlements. Given a set of entitlements, we may deduce what extension fits this intension. In other words, if we know what a given citizenship consists in (i.e. the rights and duties that are connected to the status) we are in a position to tell, consistently with the content of the status, which criteria for acquisition and loss are consistent with the entitlements.

If the characterisation of the relationship between intension (D) and extension (C) in terms of functional correlation is correct, we obtain a standard for evaluating the appropriateness of criteria for acquisition and loss. We can thus analyse the internal consistency of the design of a given citizenship policy. The functionalist theory offers a standard against which we can test whether granting citizenship is justified; or, if you prefer, a standard allowing for principled reasoning about the design of citizenship laws.

If the design is to be consistent, extension will follow intension in such a way that to who citizenship is granted must depend on what citizenship consists in. Here are three examples taken from well-known approaches to citizenship. First example: If we assume that the intension is given by, for example, political autonomy, it is consistent that extension is determined by, for example, adulthood (proxy for maturity). Therefore, age is a reasonable criterion for access to franchise. Second example: If the intension is given by, for example, subjecthood to the legal order, then it is consistent that extension is determined by, for example, birth on the territory (proxy 
for physical presence). Therefore, ius soli is a reasonable for criterion for acquisition of citizenship. Third example: If the intension is given by, for example, ensuring transgenerational solidarity, then it is consistent that extension is determined by, for example, descent or family ties. Therefore, ius sanguinis is a reasonable criterion for acquisition of citizenship.

It is important to notice that the standard is not reliant on factors that vary with the observer, for example, political opinion, worldview, conceptions of the good and more. It relies on internal consistency between input data (i.e. which legal positions - rights and duties - a given citizenship consists of) and output data (i.e. criteria for acquisition and loss).

\subsubsection{How Can it be Applied to Brexit?}

From the functional perspective, EU citizenship is more similar to national citizenships than one might expect, notwithstanding the wording of the annexed Declaration to the Danish Act of Ratification of the Maastricht Treaty that states: 'Nothing in the Treaty on European Union implies or foresees an undertaking to create a citizenship of the Union in the sense of a citizenship of a nation-state. ${ }^{, 12}$ Conceptually, both are middle-terms allowing connection between, on the one hand, criteria determining acquisition and loss and, on the other, entitlements associated with the status.

In keeping with the theory, we should start by distinguishing between, on the one hand, criteria determining access to the status and, on the other, the content of citizenship. It enables to visualise the characteristic bi-dimensionality of citizenship. We can thus see how the problem of vested or acquired rights emerges in the first place: The EU citizenship status, created by the EU Treaties, may be additional and thus have no independent existence following a State's withdrawal from the EU for the nationals of that member state, but the material implication need not be that rights of citizens disappear.

The bi-dimensionality of citizenship shows gaps and asymmetries that arise between having access to the status and enjoying the rights connected to it. Such asymmetries are normatively suspicious (they lower the internal consistency of the status) but they sometimes appear as a matter of legal fact. The bi-dimensionality of citizenship explains why the consequences of constitutional territorial permutations for the enjoyment of supranational rights are not straightforward. Possession of citizenship status is non-territorial, even though rights attached to the status may be territorial. 
Bi-dimensionality may thus demonstrate how state succession produces new foreigners who are affected by 'quasi-loss' of EU citizenship status (or invalidation ex tunc of the status) resulting in the impossibility to access rights. ${ }^{13}$ Bi-dimensionality also explains the asymmetries involved in cases in which people lost rights without losing the status due to racist immigration policies; ${ }^{14}$ or how others have the status but with a reduction of its content, like Manxmen and Channel Islanders who may vote for the European Parliament but are prohibited from free movement unless they reside five years in the UK; or how the Faroe islanders never had the status but de facto access (some) rights. The people of the Faroe Islands are Danes but not EU citizens. The Danish government added a protocol specifying that 'the Danish nationals' of the islands were not 'nationals for the purposes of Community law ${ }^{15}$ - which is basically the predecessor status of Union citizenship. Yet this limitation of the scope of application has virtually no impact on the Faroe islanders: 'Given that limitation was merely territorial, there is no evidence that it has in any way affected the enjoyment of EU citizenship by the Faroe islanders, as long as they do not travel on the green Faroe model of the Danish passport, which they can, but are not obliged to request' (Kochenov 2016).

Such asymmetries are easily spotted on the background of the bidimensionality that the functionalist theory builds on.

From a normative standpoint, the functionalist theory also holds such gaps to be unwarranted. The core design idea of the functionalist theory, as foreshowed above, is that legitimacy is dictated by fittingness of criteria (for acquisition and loss) to content. Depending on which entitlements are considered to be determinative of the content of EU citizenship, the relevant feature that people need to have to access these rights will change. This reflects on criteria for loss of the status as well. Such criteria stand in functional correlation to the content of citizenship in the same way as criteria determining acquisition. A first indication of this is of course that the rules on loss of citizenship vary remarkably across states, at least as much as the rules on the acquisition of citizenship (Vink and De Groot 2010; Vink and Chun Luk 2015). Consider, for example, the following:

Insofar as the entitlement that European citizenship is connected with is, say, the special right to consular protection, then a relevant feature is reciprocity of recognition or equal privileges, for which - commonly and not unreasonably - having the nationality of a member state is taken to be a proxy. Reasoning under such an assumption means it would be legitimate to withdraw European citizenship because there is no reciprocity of 
recognition on grounds of nationality (since, in the event of Brexit, the UK would no longer be a member state). It is so precisely because the entitlement attached to the status basically is a privilege to which one may cling only insofar as the reciprocity ground is upheld.

Insofar as the entitlements connected to European citizenship are such that the status is destined to be the fundamental status of Member State nationals - to use a famous phrasing of the ECJ - then, a relevant feature would be that of being fundamentally linked to, or affected by, the Union. Affectedness may stand as a proxy for 'having ties to.' Entitlements would not amount to mere privileges or special rights, but would need to embody supranational features. A case in point is supranational political rights. It would be legitimate to withdraw the status from those who no longer are affected by EU law but it would be illegitimate to withdraw the status from those who are enjoying it as long as they are affected. Will post-Europeans be affected by EU law? If they live in the Union, they surely will. Consequently, to strip them of their 'fundamental status' would be illegitimate. If they do not live in the Union the situation is different. It might be illegitimate to withdraw the status of those whose rights are frozen, depending on which these are. It will turn, in part, on which rights are frozen and whether the loss of status can be challenged.

Depending on what is held to be the content of European citizenship, criteria for withdrawal of the status will vary. The functionalist theory provides us with a standard against which we can test under which conditions withdrawal is legitimate.

But it also provides information in the other direction: Given a set of criteria for acquisition and loss, we may infer knowledge of the nature and type of entitlements compatible with such a set. ${ }^{16}$ The same is true for criteria determining loss. Under which conditions is withdrawal of status (il)legitimate? Answering provides an indirect source of information about which entitlements are attached to the status.

Both of these directions are important when we want to understand European citizenship after Brexit: If loss can be determined solely at domestic level, are entitlements still supranational rights? Vice versa, if entitlements are supranational individual rights, can loss be univocally determined by a Member State? In the next two chapters I explore both directions of inquiry. In the final chapter, I draw some conclusions about the nature of Union citizenship.

Consistently with the theory, 'who gets to judge legitimacy of withdrawal of supranational entitlements?' is a question the answer to which 
cannot be any member state that so wishes. A fortiori, this authority cannot lie with a former member state - who would then have full authority to judge over the legitimacy of withdrawal of supranational entitlements in a Union of which it is no longer part! If loss is imposed unilaterally and unconditionally by a member state, it is an indication of the fact that the entitlements that the status consists in are at most mutually recognised privileges. If grounds for loss are not unilaterally determined at domestic level, this very fact can be taken as an indication of, albeit not full proof of, the supranational nature of at least some entitlements.

Without looking to pre-empt the results of my inquiry in the next sections, it turns out that as far as criteria determining loss are concerned, there are limits to what States can do, even within their domaine réservé and this may prove to have repercussions in domestic legislation even after exit. In particular, the UK has strong incentive to reform its nationality and immigration law to avoid instrumental naturalisation and abuse of multiple citizenships. But European law imposes limits to what the UK can do to protect itself against this indirect way of undermining the point of Brexit. There are also things that the (citizenry of the) Union could do. As far as content is concerned, (some) rights may be frozen, but they are not those making Union citizenship a supranational legal status. The legal grounds enabling freezing are international, not European. This will be so at least until the EU adheres to the European Convention of Human Rights, an idea that lost traction in the wake of the ECJ's Opinion 2/13 from 2014. Other rights can be saved, but it would require decoupling the concepts of nationality and Union citizenship. If the EU sees Union citizenship as a fundamental status, it need not depend on the idiosyncrasies of the application of domestic nationality laws. In Brexit, to save the supranational rights connected to Union citizenship, certain groups of people who lose member state nationality would need to keep their connection to the Union. The windows of legal opportunity for such creative solutions are very small. To determine which, let us see how rights can be frozen.

\section{Notes}

1. OJ L 29, l February 1985.

2. See also Status of Greenland: Commission opinion, COM (83) 66 final, 2 February 1983. 
3. Quote from House of Commons 2013, at 15.

4. See Mindus 2014, third chapter on definitions in legal science.

5. Case C-184/99 Rudy Grzelczyk v. Centre public d'aide sociale d'OttigniesLouvain-la-neuve (2001) ECR I-6193, \$ 31. But also Case C-224/98 D'Hoop [2002] ECR I-6191 \$ 28; Case C-148/02 Avello [2003] ECR I-1161 \$ 22; Case C-403/03 Schempp [2005] ECR I-6421 \$ 15.

6. On the evolution of the two major frameworks for assessing European integration, see de Búrca 2012, esp. at $126 \mathrm{ff}$.

7. The literature on mutual recognition is growing: see Lenaerts 2015; Janssens 2013; Möstl 2010; Schmidt 2008; Nicolaïdis 2007; Padoa Schioppa 2005.

8. Middle-terms are neither true nor false. They are to be retained if they make a consistent connection between premises and conclusions. They are to be rejected otherwise.

9. The formula was coined by the US Supreme Court in Trop v. Dulles, 356 U.S. 86, 101 (1958), at 355.

10. Aristotle combines quantitative and qualitative criteria in his theory on forms of government. The two criteria are: number of citizens sharing political power and whether power is exercised in the interest of the power-holder. See Mindus 2014, Chapter 2.

11. In what follows I shall express the relation between intension (Domain) and extension (Codomain) in mathematical terms borrowed from naïve set theory: see Halmos 1960.

12. Declaration on the citizenship of the Union to be associated to the Danish Act of Ratification [1992] OJ C348/1.

13. For example, Kaur (16 Case C-192/99 The Queen v Secretary of State for the Home Department, ex parte: Manjit Kaur [2001] ECR I-01237), a case involving a third country national who was recognised by the UK as citizen of the UK and Colonies but did not fall within the personal scope of rules relating to citizens entitled to reside in the UK, she could not rely on her Union citizenship. The European Court of Justice held that Kaur never had been a European citizen so rights never arose in the first place.

14. For example, the case of East Africans Asians in the UK. See Lester 2003.

15. Protocol n. 2 to the Act of Accession, relating to the Faro Islands, art. 4, 1972 (OJ L 73 163).

16. There is a degree of imprecision in this since citizenship constitutes a surjective function: every ground for loss (or point in the codomain) is the value of $f(d)$ for at least one point $d$ in the domain (or entitlement connected to the status). But adjustments are done at a later stage: in reflexive equilibrium between what we know about the contents of citizenship respective of what we know about the criteria for acquisition and loss. 


\section{REFERENCES}

Athanassiou, P., Laulhé Shaelou, S. (2016) 'EU Citizenship and its Relevance for EU Exit and Secession', in D. Kochenov (ed.) EU Citizenship and Federalism: The Role of Rights, Cambridge: CUP (forthcoming).

Craig, P. (2016) Brexit: A Drama in Six Acts (11 July 2016) European Law Review August 2016, available at: http://papers.ssrn.com/sol3/papers.cfm?abstract_ id $=2807975$ (last accessed 30 October 2016).

Dawson, M., Augenstein, D., 'After Brexit: Time for a Further Decoupling of European and National Citizenship?', VerfBlog, 14 July 2016, available at http://verfassungsblog.de/brexit-decoupling-european-national-citizenship/ (last accessed 30 October 2016).

De Búrca, G. (2012) 'The ECJ and the International Legal Order: A Re-evaluation', in G. De Búrca, J.H.H. Weiler (eds.) The Worlds of European Constitutionalism, Cambridge: CUP.

Douglas-Scott, S. (2015) 'Constitutional Implications of a UK Exit from the EU: Some Questions that Really Must be Asked', U.K. Const. L. Blog, (17 April 2015), available at https://ukconstitutionallaw.org/2015/04/17/sionaidhdouglas-scott-constitutional-implications-of-a-uk-exit-from-the-eu-some-ques tions-that-really-must-be-asked/ (last accessed 30 October 2016).

Halmos, P. (1960) Naive Set Theory, Dordrecht: Springer.

House of Commons (2013) Leaving the EU Report of House of Commons, available at http://researchbriefings.parliament.uk/ResearchBriefing/Summary/ RP13-42\#fullreport (last accessed 30 October 2016).

House of Lords EU Committee Report on The Process of Withdrawing from the European Union 11th Report of Session 2015-16, available at: http://www. publications.parliament.uk/pa/ld201516/ldselect/ldeucom/138/138.pdf (last accessed 30 October 2016).

Janssens, C. (2013) The Principle of Mutual Recognition in EU Law, Oxford: Oxford University Press.

Kochenov, D. (2011) EU Law of the Overseas, Dordrecht: Kluwer Law International.

Kochenov, D. (2016) EU Citizenship and Withdrawals from the Union: How Inevitable is the Radical Downgrading of Rights?, LEQS Paper No. 111/2016, available at http://www.lse.ac.uk/europeanInstitute/LEQS\%20Discussion\% 20Paper\%20Series/LEQSPaper111.pdf (last accessed 30 October 2016).

Laffont, P. (1979) Histoire de la France en Algérie, Paris: Plon.

Lenaerts, K. (2015) 'The Principle of Mutual Recognition in the Area of Freedom, Security and Justice', The Fourth Annual Sir Jeremy Lever Lecture, University of Oxford, 30 January 2015, available at https://www.law.ox.ac.uk/sites/ files/oxlaw/the_principle_of_mutual_recognition_in_the_area_of_freedom_ judge_lenaerts.pdf (last accessed 30 October 2016). 
Lester, A. (2003) Lord of Herne Hill QC, Lecture, East Africans Asians vs UK: The Inside Story, 23 October 2003.

Mindus, P. (2014) Cittadini e no. Forme e funzioni dell'inclusione e dell'esclusione, Florence: Firenze University Press.

Mindus, P. (2016) 'Citizenship and Arbitrary Law-Making: On the Quaintness of Non-national Disenfranchisement', 7 Società Mutamento Politica 13, Special Issue 'Citizenships of Our Times', available at http://www.fupress.net/index. $\mathrm{php} / \mathrm{smp} /$ article/view/18287/16968 (last accessed 30 October 2016).

Möstl, M. (2010) 'Preconditions and Limits of Mutual Recognition', 47 Common Market Law Review 405-436.

Nicolaidis, K. (2007) 'Kir Forever? The Journey of a Political Scientist in the Landscape of Recognition', in M.P. Maduro (ed.) The Past and Future of EU Law. The Classics of EU Law Revisited on the 50th Anniversary of the Rome Treaty, Hart: Oxford.

Padoa Schioppa, F.K. (ed.) (2005) The Principle of Mutual Recognition in the European Integration Process, Basingstoke: Palgrave McMillan.

Peers, S. (2016) 'Brexit: Can the ECJ Get Involved?', Blog entry at EU law analysis from 3 November 2016, available at http://eulawanalysis.blogspot.it/2016/ 11/brexit-can-ecj-get-involved.html (last accessed 7 November 2016).

Schmidt, S. (ed.) (2008) Mutual Recognition as a New Mode of Governance, London: Routledge.

Vink, M.P., Chun Luk, N. (2015) 'Mapping Statistics on Loss of Nationality in the EU: A New Online Database', in S. Carrera Nunez, G.-R. De Groot (eds.) European Citizenship at the Crossroads, Oisterwijk: Wolf.

Vink, M.P., De Groot, G.R. (2010) Birthright-Based Acquisition of Citizenship, EUDO Citizenship Comparative Analysis, RSCAS/EUDO-CIT-Comp. 2010/6, available at http://eudo-citizenship.eu/docs/Vink_DeGroot.pdf (last accessed 30 October 2016).

Ziller, J. (2005) 'L’Union Européenne et l'outre-mer', 113 Pouvoirs 145.

Open Access This chapter is licensed under the terms of the Creative Commons Attribution 4.0 International License (http://creativecommons.org/licenses/ by $/ 4.0 /$ ), which permits use, sharing, adaptation, distribution and reproduction in any medium or format, as long as you give appropriate credit to the original author(s) and the source, provide a link to the Creative Commons license and indicate if changes were made.

The images or other third party material in this chapter are included in the book's Creative Commons license, unless indicated otherwise in a credit line to the material. If material is not included in the book's Creative Commons license and your intended use is not permitted by statutory regulation or exceeds the permitted use, you will need to obtain permission directly from the copyright holder.

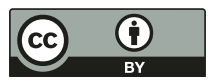

